\title{
Comparative Efficiency Analysis of Irrigation Scheme Categories of Awash River Basin, Ethiopia
}

\author{
Yusuf Kedir, Belete Berhanu and Tena Alamirew \\ Addis Ababa Institute of Technology
}

\begin{abstract}
One of resource management strategies in water scarce areas including Awash River basin of Ethiopia is through increasing water productivity. For the last two decades, with the objective of efficiency improvement, several modern water saving technologies including center pivot have been introduced to Awash basin and are operating along with different surface methods. However, performances of these technologies were not categorically assessed and compared. This review based analytical efficiency comparison has been carried out based on performance data of 24 schemes of the basin collected from published articles and printed reports. The data were filtered and synthesized. The schemes were grouped into categories and compared as sprinkler versus surface schemes; gated pipe surface schemes versus ditch systems; among small, medium and large scales; and traditional versus modern schemes. Mann-Whitney and Kruskal-Wallis nonparametric tests were used to verify existence of significances efficiency variations. The results revealed that efficiencies of individual schemes were in the range of 14.03 to $83.33 \%$ with overall mean of $37.06 \%$ and 14 of the schemes had efficiencies below the mean. More importantly, there were no significant efficiency variation among the scheme categories being compared even between sprinklers and surface methods revealing the incapability of the adopted technologies for bringing the expected advantages. Water abundances and shortages due to improper management and operation practices dictated efficiency performances than managements which led to recommend improving existing poor scheme and water management practices prior to introducing any modern technologies.
\end{abstract}

Keywords: Center pivot, Dragline, Flexible Gated Pipe, Nonparametric test, Water saving technology

DOI: $10.7176 /$ JRDM/79-03

Publication date:October $31^{\text {st }} 2021$

\section{INTRODUCTION}

Irrigation operations require resource mobilization that must be allocated and used in efficient way for implementing scheduled changes and to respond to unscheduled perturbations. In turn, resource mobilization demanded grouping of the heterogonous irrigation systems (Renault and Godaliyadda 1999). Different variables are used to categorize irrigation systems; technology, size and management are among key variables affecting irrigation management. Based on technologies to distribute and apply water, sub categories existed but the common and globally known are surface, sprinkler and drip systems. Based on farm size (the ranges might vary among countries) small, medium and large scale while based on complexity, grouping as modern and traditional or informal schemes is very common in developing countries. The factors for grouping have implications on operational behavior with ultimate goals of improving operational qualities (efficiency, performance, benchmarking, comparing etc.), and resource mobilizing and allocating for the operation (Renault and Godaliyadda 1999).

Irrigation efficiency is a performance tool that can be used to compare schemes or technologies (Burt et al. 1997). It is fundamental for improving water management at field, farm, project, district and basin scales (Ahadi et al. 2013; Burt et al. 1997;); and is commonly used to assess effectiveness of irrigation in delivering water for beneficial uses (Rudnick and Irmak 2015) or to assess resource such as energy utilization efficiency. For instance, low irrigation efficiency cause excessive use of both energy and water (Erkin 1997; Playan and Mateos 2006; Shifflett et al. 2015).

There are numerous definitions of irrigation efficiency (Burt et al. 1997; Jägermeyr et al. 2015) suggesting selection of a particular definition depends on interest of the user. The generic definition refers to the ratio of water consumed by crops relative to water applied or withdrawn from a source by assessing conveyance and application losses (Bos 1980, 1985; Bos and Nugteren 1990; Brouwer et al. 1989; Burt et al. 1997; Cai et al. 2006; Giordano et al. 2017; Hachum 2006; Howell 2003; Jensen 1967, 1993, 2007; Keller and Keller 1995). Relative Irrigation Supply (RIS) is water diverted divided by irrigation requirements (Molden et al. 1998) which can be used as inverse of irrigation efficiency (Bos et al. 1994; Molden et al. 1998).

For properly managed scheme, mean efficiency of $65 \%$ for graded furrow; $80 \%$ for hand moved (dragline) and for spray head center pivot; and $85 \%$ for drip systems have been recommended (Howell 2003; Keller and Bliesner 2000; Meriem and Keller 1978) but it can be affected by scheme sizes, conveyance and application methods, operational difficulty, management modalities, topography and soil types (Bos and Nugteren 1990) and so on.

Some argued that systems such as sprinkler are more likely to be sustainable (Burt and Styles 2007) because 
the more advanced the technology is the more effective water application is and modern technology can make a substantial difference in efficiency (Belder 2004; Zhao et al. 2010). Others suggested that advanced technology does not always ensure efficiency in irrigation (Dinar and Yaron 1992). Technology is by no means the only factor determining scheme performances and losses are often associated with poor design, construction and maintenances (Berhe et al. 2013). Efficient operation and management plays an important role (Mishra et al. 2001) and there is a wide recognition that deficiencies in management were the chief constraints of poor performances. Authors such as Jensen et al. (1967) give equal weight for both physical facilities and water management improvement. Combinations of technical changes with institutional reforms have been responsible for the success of reform in irrigation. Improperly managed 'high technology' can be as wasteful and unproductive as poorly managed traditional systems (Levidowa et al. 2014; Perry et al. 2009). Rudnick and Irmak (2015) also added that a welldesigned irrigation can perform inefficiently due to poor irrigation scheduling. Surface irrigation performance could be improved when adopting well-designed and managed systems and appropriate scheduling (Darouich 2017; Darouich et al. 2012; Pereira and Oweis 2002). They can achieve comparable efficiency to drip but requires management commitment (Burt and Styles 2007; Hanson et al. 1996) and Clemmens and Dedrick (1994) reported all irrigation methods can attain approximately the same levels of efficiency but differences appear in many areas as a consequence of design, management and maintenance which can be summarized as; efficiency depends on how well an irrigation system is designed and how it is managed or operated.

In Ethiopia, currently around 0.65 million ha is under irrigation (Yusuf 2021). However, despite the fact that irrigation supposed to boost nation's crop production, its contribution is below 2.5\% (Zemede 2011). Surface systems such as flexible gated pipe (FGP), ditch furrow, basin and traditional methods; among sprinkler technologies dragline and center pivot; drip technologies; size based small, medium and large scales and so on are common scheme categories of the country and all types are found in Awash basin. Irrigation accounts $83 \%$ of the

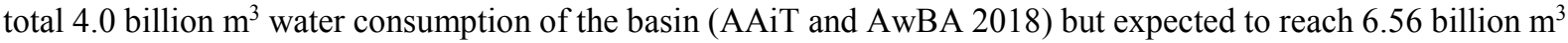
by 2030 (AwBA 2018).

Furrow methods have been widely practiced since the introduction of modern irrigation into the basin. After operating around 15 to 20 years, performances of the schemes started to decline at the end of 1970 (Rahmato 1999) and persist till this day by engulfing even lately constructed schemes. Water shortages and mismanagement (AwBA 2018, 2017), salinization (Gebremeskel and Mekonen 2015), water quality degradation, recurrent floods and droughts, and population increment are putting pressures on unsustainable irrigation of Awash basin (Endalkachew 2012; Stuart and Dave 2009; World Bank 2006).

For the last two decades, expanding irrigation and increasing efficiency (MoWR 2001) through modernization (Edossa 2014) have been key policy issues and taken as a solution for increasing food shortages and economic pressures. The introductions of FGP and sprinkler systems into the basin as alternative for ditch-furrow surface methods can be mentioned as notable evidences.

FGP is aboveground pipe used for distributing water into furrow and can either be rigid or flexible. It is widely used because of its low cost and space to store as well as ease of transporting (Smith and Gillies 2009). According to Hassan (1998), it has made furrow system more efficient; easier to operate and maintain; can attain 35 to $60 \%$ water and labor cost reduction; provides uniform distribution into furrows; and reduce seepage and evaporative losses. A study in Egypt revealed that a minimum of 14\% efficiency advantage was obtained from the use of FGP by saving seepage and evaporation losses of the ditch system (Ali and Mohammed 2015). The technology has the capacity to achieve more than $70 \%$ application and $90 \%$ distribution efficiencies (Omara 1997) and if recycling is used, up to $90 \%$ application efficiency can be attained (Tilly and Chapman 1999). However, good design with land leveling (Osman 2000) and proper operations are required. Otherwise, they are vulnerable for rupture (Mengistu et al. 2017).

The other introduced technologies are dragline and center pivot sprinkler systems. Efficiency of sprinklers depend on pressure head and spacing, type and design to suit the soils, crop characteristics and wind conditions. They can achieve high application and distribution efficiencies. However, wind distortions, high investment and energy consumption, and quality water requirement are among their drawbacks (Mateos 1998).

However, old fashioned and traditional practices continue in the basin. Irrigation schemes are characterized by incomplete and poor construction qualities; lack of drainage facilities, malfunctioning structures, maintenance services; over or under irrigation; complete absence of scheduling and water measurements; seepages, leakages, drains losses; and etc. all contributing for low performances (Girma and Solomon 2016; Yusuf 2015). Lack of skills and knowledge, rules and guidelines; inappropriate and incompatible institutional setup; poor cooperation of stakeholders; and etc. are major water governance challenges of the basin (AAiT and AwBA 2018).

With all these international debates, lists of local challenges and principally absence of locally generated performance data, Ethiopian government targeted to increase irrigated areas of Awash basin by $70 \%$ at the end of 2030 (WWDSE 2013), and coverage of water saving technologies to $30 \%$ as well. The notion of efficiency increment seems totally imprisoned in importing of new technologies by ignoring the management aspects. According to EPCC (2015), evaluating water development activities to identify critical problems thereby ensure 
future resource allocations based on efficient use is very important. Expanding water saving technologies on the basis of efficiency advantages (MoWIE 2020) without knowing existing performances of scheme categories and efficiency advantages of introduced technologies contradict the EPCC (2015) recommendation and led the authors to raise the following questions; 1) Does the introduced technologies brought efficiency improvement? 2) Do efficiency differences manifested on scheme categories of the basin? 3) Adopting modern technologies or improving scheme and water management practices is a priority for irrigation sector of the basin?

The paper tried to shed lights on effectiveness of the adopted technologies and could help to assess existences of efficiency differences among scheme categories because the selected categories are bases for national development strategies, programs, and interventions. To be successful, representative efficiency figures in a way that can be useful for policy makers is vital. Despite relatively rich literatures focused on irrigation performances worldwide, in Ethiopia they are few, fragmented and scheme based (Awulachew et al. 2007). Besides, reference materials on literature based efficiency comparison of scheme categories using nonparametric tests cannot be found and this article might be the first to use such approaches. In order to address the questions, efficiency data of 24 schemes were grouped, statistically compared and discussed further. Although it is difficult to be sure that all published reports were accessed, the authors believed that the data being used and the analysis methods suffice to provide insights address the questions.

\section{MATERIALS AND METHODS}

\subsection{Descriptions of irrigation in Awash Basin}

Awash, one of the 12 river basins of Ethiopia, accounts $25 \%$ of national agricultural production and hosts more than $65 \%$ of total industries. The basin is the second most populous (18.6 million) basin next to Abay; fourth in areal coverage with $114,123 \mathrm{~km}^{2}$; seventh in annual runoff volume; and is the most intensively irrigated basin (AwBA 2018). Modern irrigation of the country was started in Awash basin (Awulachew et al. 2007; Bekele et al. 2012; Haile and Kassa 2015; Rahmato 1999) after the construction of Koka dam in 1960s. In the early 70s, out of 0.1 million ha modern irrigation of the country, 50\% was found in Awash (Rahmato 1999). Currently around 0.2 million ha, which is $9 \%$ of the basin's rainfed cropland and $32 \%$ of irrigated area of the country, of the basin is under irrigation (AAiT and AwBA 2018; AwBA 2018; Karimi et al. 2014; Yibeltal 2013).

Regarding irrigation potential of the basin, variations within the range of 0.13 to 0.4 million ha reported (Awulachew et al. 2010; FAO 1965). However, WWDSE (2013) stated that around 0.179 million ha new irrigation area was planned (site locations of these planned were listed) to be added on the existing 0.187 million ha (Yibeltal 2013) by federal and regional states demonstrating the potential to reach as high as 0.4 million ha.

Koka, Tendaho and Kessem, with cumulative storage capacity of 3.16 billion $\mathrm{m}^{3}$, are the three main dams existing in the basin regulating the Awash and the tributary Kessem rivers flow for irrigation purposes. Koka dam, located in the upper valley, is important for hydropower generation and irrigation. The other two dams are located in the middle and lower valley, respectively, to provide water for irrigation and household purposes (Mahtsente et al., 2019). More than 2,500 equipped irrigation schemes (Yibeltal 2013) of surface, dragline and center pivot sprinklers, and drip types are functioning. Almost $97.9 \%$ area of the basin is irrigated with surface methods from which around $87 \%, 10.6 \%$ and $2.4 \%$ are ditch-furrow, FGP and basin methods, respectively. Shares of sprinkler and drip systems are $1.46 \%$ and $0.64 \%$. Around $31 \%$ of the schemes are sugarcane, cotton, fruits, and vegetables producing private and state owned or public commercial medium and large schemes which are concentrated along the river course (AwBA 2018). Small schemes are concentrated in the upper part of the basin along tributaries of Awash River (Fig 1) and mostly used for production of cereals and vegetables. Almost $62 \%$ and $38 \%$ of irrigated area is covered by modern and traditional (informal) schemes while $23 \%$ and $71 \%$ of the area use motor pumps and diversions, respectively. Only $2.10 \%$ of the irrigated area use groundwater. Maize, onion, sugarcane, cotton and tomato are dominant crops covering $76 \%$ of irrigated area with individual coverage of $23.35 \%, 18.42 \%$, $15.60 \%, 13.48 \%$, and 5.50\%, respectively (Yibeltal 2013). Fruits, stimulants, root crops, pulses, and flowers are also irrigated but with small proportion.

Basin method is localized in few fruit producing surface irrigated schemes such as Tibila and Nura Era. All surface schemes use block-ended short furrows and water is diverted either by opening and closing of field ditches or siphoning from the ditches. 


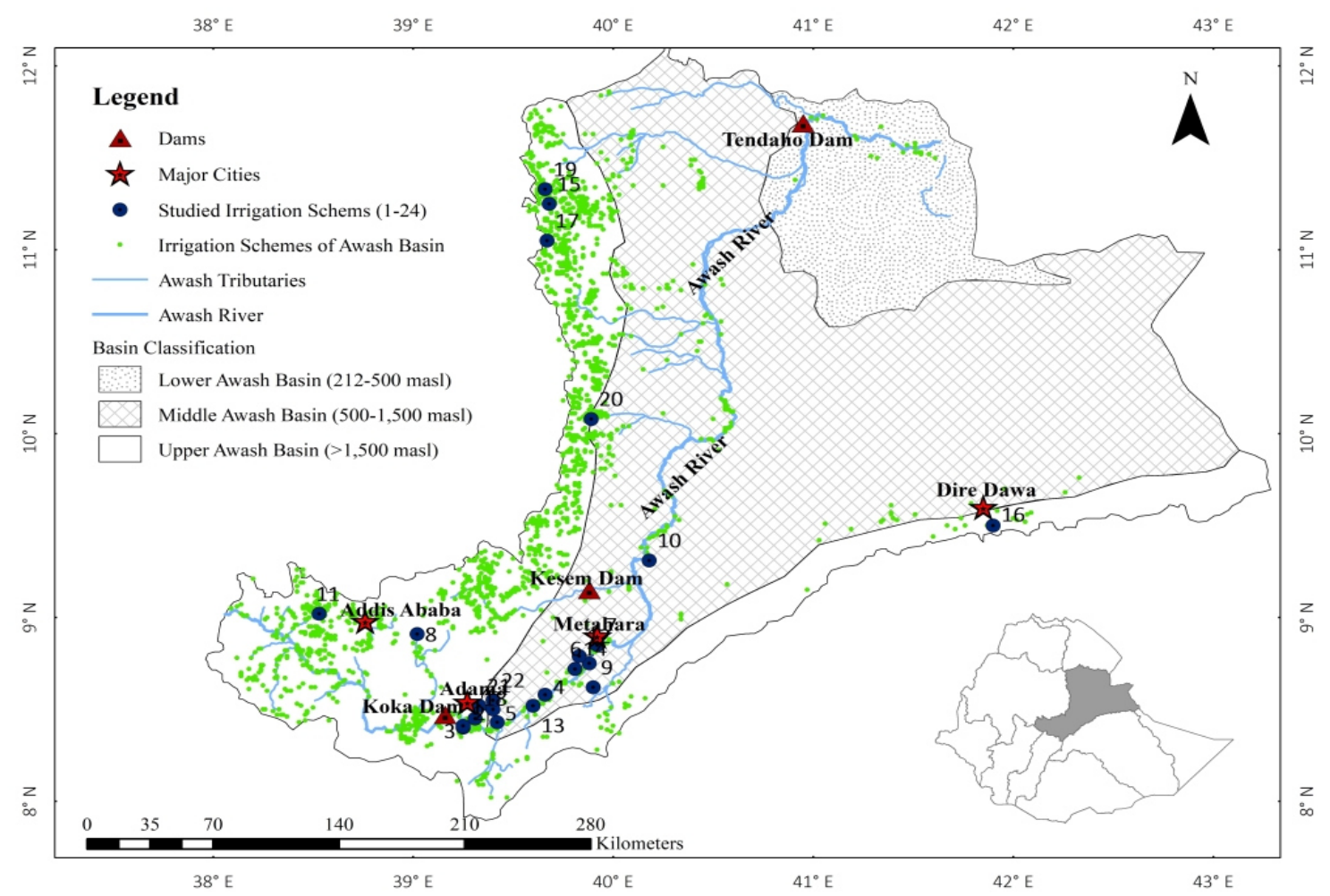

Fig 1 map displaying all existing irrigation schemes (both color spots) and dams in Awash River basin. The black (blue) spots represent irrigation schemes listed from 1 to 24 in Table 1. QGIS free version software was used to develop the map.

FGP (commercially known of flexi and hydro flumes) with non-sliding gates were introduced to Merti scheme in 2005/6 (Solomon et al. 2017) then expanded to Tendaho, Kessem, and Wellenchiti schemes (Mengistu et al. 2017). Furrows of these sugarcane schemes have been designed for $5 \mathrm{lit} / \mathrm{sec}$ inflow rates. Diameters of the pipes are 200 or $425 \mathrm{~mm}$ with designed capacity of 100 and $200 \mathrm{lit} / \mathrm{sec}$, respectively, hence, when irrigating adjacent fields, 10 or 20 outlets from opposite sides will be opened otherwise all 20 or 40 outlets will be used (Solomon et al. 2017).

The first dragline and center pivot sprinklers for the basin were installed in 2004/5 and 2010/11 at Wonji sugar factory. Currently few private farms started to use center pivot systems. Dragline sprinklers are still limited at Wake Tiyo and Dodota sugarcane farms of Wonji sugar factory. Irrigation is practiced during day times by shifting the $4 \mathrm{~m}$ risers manually or by hand at predefined irrigation intervals. Nine center pivots, each irrigating on average 75 ha at Dodota farm of Wonji, are operating continuously with preset rotation speed and application rates.

\subsection{Data Sources}

Both digital and printed materials were used as data sources. Peer reviewed journal articles of recognized publishers, proceedings, research and study reports, $\mathrm{PhD}$ and $\mathrm{MSc}$ dissertations and theses etc. from recognized universities, national and international organizations were the major data sources. Databases of Google Scholar, Science Direct, Research Gate; university repositories such as Addis Ababa Institute of Technology, Haramaya, Arba Minch and so on were major sources of digital materials. Communications with research institutes, federal and regional organizations, and professionals were also contacted to collect printed materials.

Standard techniques were applied while searching the accumulated information from web sources without limiting the time period. Key words such Awash River basin; irrigation schemes; conveyance efficiency; application efficiency; irrigation efficiency; water management; water use efficiency; performance evaluation and etc. either separately or in combination were used. In some instances, names of widely known irrigation schemes in the basin were also combined with the key words for searching.

After collecting available publications, papers focusing on irrigation efficiencies were selected based on their relevance, and their data collection and analysis methods. Discussions with irrigation personnel and experts and experiences of the authors regarding irrigation practices of the basin were also used while filtering the data.

\subsection{Irrigation Scheme Categorization}

In Ethiopia, there is no clearly defined and standardized criteria and legal framework to categorize irrigation 
schemes. Several variables are commonly used such as sizes, natures of the water sources, management types, water conveyance and application methods, infrastructure conditions and so on. With some variation, informal but widely accepted categorizations based on scheme sizes, infrastructure conditions, and water conveyance and application methods have been used by scholars and stakeholders (Awulachew et al. 2005).

Based on size, schemes of the country are small (less than 200 ha), medium (200 to 3,000 ha) and large (over $3,000 \mathrm{ha}$ ) scales. The second classification use mixed criteria, scheme condition and ownership, and categorize as traditional, modern communal, modern private and public (Makombe et al. 2017) which can be reduced broadly into traditional and modern. Traditional are usually with temporary diversion weirs maintained annually by users and are mostly earth canals. The moderns are with permanent weirs (including micro-dams), flow control and distribution systems constructed by either governmental or nongovernmental organizations. In some cases their primary and secondary canals might be lined (Awulachew et al. 2005; Hagos et al. 2009; Makombe et al. 2011, 2017; Zeleke et al. 2016). Most often, medium and large scales are managed by public (government) or private.

By considering the above facts and crude classification, irrigation schemes for which efficiency data were grouped into the following categories and compared in the following manner: 1) surface versus sprinkler systems; 2) FGP surface schemes versus surface schemes with ditch-furrow systems; 3) large, medium and small scale schemes; and 4) traditional verses modern schemes.

The first two directly focuses on the types of irrigation technologies being used and will help to address the first question raised in the introduction part while the other two are included to address the second question.

\subsection{Data Synthesis and Statistical Analysis}

The study was intended to compare overall irrigation efficiencies (volume of water beneficial used with respect to diverted) of categorized irrigation schemes based on data of individual schemes without considering the factors for water losses as well as water accounting at basin scale.

In such cases, it is not expected to find complete reported data fitting the study objectives due to differences of interests among researchers. The reviewed papers mostly focused on quantifying and reporting of efficiency parameters related to RIS, application, conveyance, distribution, adequacy and storage for surface schemes while conveyance, application, distribution uniformity, and etc. for sprinklers. A single parameter might be reported only in a single article for one or two schemes; or, several articles published in different time periods might report a single or more than one parameter for a scheme. For instance, conveyance and application efficiencies of a scheme might be reported in one or two or more articles being studied in different seasons with different scales then published independently. Hence, the reviewed data were found to be heterogeneous in time and scale, and most importantly few in numbers. In such cases, it is imperative to synthesize (determining total irrigation efficiencies based on reported data of appropriate parameters) and to normalize them whenever necessary.

Total efficiencies were determined either by inverting RIS value of a given scheme whenever possible or in other cases by multiplying respective conveyance and application efficiency data of particular surface schemes. For sprinklers, if the total efficiency of a schemes was reported, the value was directly used otherwise reported low quarter distribution and application efficiencies were multiplied with conveyance efficiency of a given scheme (Merkley and Allen 2004).

Many authors stated that irrigation efficiencies are difficult to compare between studies (Burt et al. 1997; Jägermeyr et al. 2015) due to its dynamic nature (Ahadi et al. 2013). Nevertheless, classical irrigation efficiency in which dynamic nature is often lost at local and temporal scales which focus on discrete time periods or spatial concept (Ahadi et al. 2013) was considered to normalize the variations because it is a valid indicator commonly used to assess effectiveness of irrigation system in delivering water for beneficial uses (Bos 1997; Rudnick and Irmak 2015). Besides, most of the data were published after 2000, which was reasonably short period to perceive significant changes on irrigation practices of the basin. However, in some cases, area weighted means (Ahadi et al. 2013; Bittinger et al. 1979) for schemes grouped under a given category were indicated.

In reality, moreover, it is difficult to find normally distributed large data with regard to scheme performance studies for specific river basin especially in developing countries. The collected data were not sufficient (were less than 20) to perform parametric statistical analysis but were useful to infer conclusions if proper test is applied (Nachar 2008). Fortunately, there are statistical tests to compare independent groups that do not require large normally distributed samples. The Mann-Whitney $U$ and Kruskal-Wallis nonparametric statistical tests are appropriate methods that suit the study because they are independent of any assumption about the distribution of population so are called distribution free and are very robust. They can be used to answer the questions of the researcher concerning the difference between his groups. Their popularity may be attributed to their usefulness in disciplines such as engineering and manufacturing, medicine, soil science, biology, psychology, behavioral science and education (Nachar 2008; Ostertagová et al. 2014). In this study, hence, Mann-Whitney U Test and KruskalWallis tests were applied to compare two and three scheme categories, respectively. 


\section{RESULTS}

\subsection{Natures of the Reviewed Papers}

Research on irrigation management and drainage in Ethiopia was initiated in 1964 at Werer Agricultural Research Center (Paulos et al. 2002) which is located in the Awash River basin, where modern irrigation was started in 1950s (Haile and Kasa 2015; Bekele et al. 2012). The main focus was on plot based irrigation agronomy, drainage and water quality (Paulos et al. 2002). Few performance reports started to be published during 1980s and 90s. However, there is no responsible institution to set goals and priorities, to finance, to standardize methodologies, to organize and monitor performance evaluation activities which might contribute for data scarcity and heterogeneity as well. While reviewing, it was observed that the task seems completely left for PhD and MSc Students. Few irrigation schemes were evaluated repetitively due to locational advantages and data availability.

Total numbers of reviewed papers focusing on efficiencies parameters for the schemes were twenty nine published between 1986 and 2019 in journals (9 articles), PhD dissertations and MSc theses (12), proceeding (1), and study reports (7). Almost 90\% were published after 2000 while $65.5 \%$ were after 2010 . All the journal articles, except one, were products of $\mathrm{PhD}$ and MSc studies. Around 13 papers reported RIS values of twelve schemes while only 4 papers reported total irrigation efficiencies for 3 schemes.

Almost $80 \%$ of the schemes were surface systems; three of them use FGP while 16 schemes are ditch system. Only five schemes (covering 3,064 ha) use sprinklers (one center pivot and four draglines) all belong to Wonji sugar factory. Numbers of small, medium and large schemes were ten, nine and five, respectively. Twenty schemes were modern systems comprising both surface and sprinklers. Wonji main (6 papers), Fentale (5) and Amibara (4) schemes were the most reported schemes. On the contrary, almost half of the schemes were studied only once. Half of the papers were reported on nine sugarcane producing schemes. For the sprinklers, data were collected from seven papers. Papers comparing efficiencies of two (or more) schemes and focusing on a single scheme, respectively, were thirteen and sixteen in number.

\subsection{Efficiencies of Individual Irrigation Schemes; an overview}

General features, total efficiencies, and data sources regarding the reviewed irrigation schemes of Awash basin are summarized in Table 1.

The difference between the maximum and minimum irrigation efficiency values among the schemes was almost 70\%. Wonji main, Amibara, Merti and Kelena schemes had satisfactory efficiencies with respect to their irrigation methods but lower than design efficiencies which were 50\% for Amibara (Halcrow 1983), and 60\% for Wonji main and Merti schemes (Mukherji 2001).

Overall mean efficiency of the schemes was $37.06 \%$ with weighted mean of $33.67 \%$ which was calculated by adding products of irrigation efficiency and area of each schemes then divided by total area of the schemes. More than 58\% irrigation schemes had efficiencies below the mean value (Fig 2). Only three schemes had efficiency above 50\%. Four schemes had efficiency below 20\% (Tendaho and Ulaga zone-200) and above $70 \%$ (Godino and Bobe) both can be considered as exceptional for existing scheme and water management practices. Table 1 Names, irrigation technologies, farm sizes, cultivated crops, irrigation efficiencies and sources of information for each of irrigation schemes included in the analysis.

\begin{tabular}{|c|c|c|c|c|c|c|c|c|c|c|c|}
\hline No & Schemes & Years & $\begin{array}{c}\text { Areas, } \\
\text { ha }\end{array}$ & Technologies & Sizes & $\begin{array}{c}\text { Canal } \\
\text { networks }\end{array}$ & Applications & Conditions & Crops & Efficiencies, \% & Sources \\
\hline 1 & $\begin{array}{l}\text { Wonji main } \\
\text { surface }\end{array}$ & 1954 & 5,928 & Surface & Large & Lined \& earthen & Furrow & Modern & Sugarcane & 43.00 & $\begin{array}{l}\text { Beshir and Awulachew 2007; } \\
\text { Awulachew and Mekonen 2011; } \\
\text { Birhanu et al 1996; Mukherji 2001; } \\
\text { Yusuf 2015; Zeleke } 2014\end{array}$ \\
\hline$\frac{2}{3}$ & $\begin{array}{l}\text { Dodota pivot } \\
\text { Dodota Dragline }\end{array}$ & $\begin{array}{l}2010 \\
2010\end{array}$ & $\begin{array}{r}642 \\
1.600\end{array}$ & $\begin{array}{l}\text { Center pivot } \\
\text { Dragline }\end{array}$ & $\begin{array}{l}\text { Medium } \\
\text { Medium }\end{array}$ & $\begin{array}{l}\text { Pipes } \\
\text { Pipes }\end{array}$ & $\begin{array}{l}\text { Sprinkkers } \\
\text { Sprinkers }\end{array}$ & $\begin{array}{l}\text { Modern } \\
\text { Modern }\end{array}$ & $\begin{array}{l}\text { Sugarcane } \\
\text { Sugarcance }\end{array}$ & $\begin{array}{l}59.00 \\
4500\end{array}$ & $\begin{array}{l}\text { Tadesse et al 2018; Tsegaye } 2019 \\
\text { Tadesse et al 2018; Tsegaye 2019 }\end{array}$ \\
\hline 4 & $\begin{array}{l}\text { Wake Tiyo } \\
\text { Dragline }\end{array}$ & 2006 & 600 & Drag line & Medium & Pipes & Sprinklers & Modern & Sugarcane & 31.00 & $\begin{array}{l}\text { Dereje and Megersa 2015; Dereje } \\
\text { et al 2017; Tadesse et al 2018 }\end{array}$ \\
\hline 5 & $\begin{array}{l}\text { Wellenchiti } \\
\text { surface }\end{array}$ & 2010 & 800 & Surface & Medium & $\begin{array}{l}\text { Lined, geo } \\
\text { membranc, gated } \\
\text { pipe }\end{array}$ & Furrow & Modern & Sugarcane & 25.00 & Alemaychu 2018 \\
\hline 6 & $\begin{array}{l}\text { Ulaga zone-100 } \\
\text { Uhaga zonc-200 }\end{array}$ & $\begin{array}{l}2013 \\
2013\end{array}$ & ${ }_{63}^{164}$ & $\begin{array}{l}\text { Dragline } \\
\text { Draglinec }\end{array}$ & $\underset{\substack{\text { Small } \\
\text { Small }}}{-}$ & $\begin{array}{l}\text { Pipes } \\
\text { Pipes }\end{array}$ & $\begin{array}{l}\text { Sprinklers } \\
\text { Sprinkers }\end{array}$ & $\begin{array}{l}\text { Modern } \\
\text { Modern }\end{array}$ & $\begin{array}{l}\text { Sugarcane } \\
\text { Sugergane }\end{array}$ & 47.62 & $\begin{array}{l}\text { Kassa } 2015 \\
\text { Kassa } 2015\end{array}$ \\
\hline 8 & $\begin{array}{l}\text { Muaga zonc-200 } \\
\text { Merti (Metehara) }\end{array}$ & $\begin{array}{l}2013 \\
1965\end{array}$ & $\begin{array}{c}63 \\
7,060\end{array}$ & $\begin{array}{l}\text { Dragline } \\
\text { Surface }\end{array}$ & $\begin{array}{l}\text { Small } \\
\text { Large }\end{array}$ & $\begin{array}{l}\text { Pipes } \\
\text { Unlined and }\end{array}$ & $\begin{array}{l}\text { Sprinklers } \\
\text { Furrow }\end{array}$ & $\begin{array}{l}\text { Modern } \\
\text { Modern }\end{array}$ & $\begin{array}{l}\text { Sugarcane } \\
\text { Sugarcane }\end{array}$ & $\begin{array}{l}14.03 \\
46.00\end{array}$ & $\begin{array}{l}\text { Kassa } 2015 \\
\text { Awulachew and Mekonen 2011; }\end{array}$ \\
\hline 9 & Tendaho & 2009 & 11,300 & Surface & Large & $\begin{array}{l}\text { gated pipe } \\
\text { Geo membranc, } \\
\text { earthen and gated }\end{array}$ & Furrow & Modern & Sugarcane & 17.01 & $\begin{array}{l}\text { Zeleke 2014 } \\
\text { Tadesse } 2017\end{array}$ \\
\hline 10 & $\begin{array}{l}\text { Amibara (Melka } \\
\text { Sedi-Melka, } \\
\text { Werer and } \\
\text { others) }\end{array}$ & 1980 & 10,322 & Surface & Large & $\begin{array}{c}\text { pipe } \\
\text { Unlined }\end{array}$ & Furrow & Modern & $\begin{array}{l}\text { Cotton (partly } \\
\text { sesame, banana, and } \\
\text { vegetables) }\end{array}$ & 43.00 & $\begin{array}{l}\text { Awulachew and Mckonen 2011; } \\
\text { Gedion 2009; Shimelis 2004; } \\
\text { Tefera 1986 }\end{array}$ \\
\hline 11 & Godino & 1980 & 409 & Surface & Medium & Unlined & Furrow & Modern & $\begin{array}{l}\text { Vegetables, cercals, } \\
\text { sugarcane }\end{array}$ & 83.33 & Zeleke 2014 \\
\hline 12 & Goha Worku & 2001 & 150 & Surface & Small & $\begin{array}{l}\text { Masonry \& } \\
\text { carthen }\end{array}$ & Furrow & Modern & $\begin{array}{l}\text { Vegetables, cercals, } \\
\text { sugarcane }\end{array}$ & 32.00 & Birhanu 2006; Zeleke 2014 \\
\hline 13 & Gologota & 1969 & 600 & Surface & Medium & Unlined & Furrow & Traditional & Vegetables, cercals & 22.00 & Zeleke 2014 \\
\hline 14 & Batu Degaga & 1992 & 60 & Surface & Small & Lined & Short furrow & Modern & Vegetables, cereals & 39.00 & Yusuf et al 2007 \\
\hline 15 & Doni & 1997 & 89 & Surface & Small & Lined & Short furrow & Modern & $\begin{array}{l}\text { Vegetables, cerceals, } \\
\text { fruits, sugararcane, }\end{array}$ & 36.00 & Yusuf et al 2007 \\
\hline 16 & Bobe & & 57 & Surface & Small & Lined \& earthen & Furrow basin & Traditional & Vegetables & 71.43 & WB and GIRDC 2019 \\
\hline 17 & Fentale & 2009 & 5,880 & Surface & Large & $\begin{array}{l}\text { Geo membranc, } \\
\text { concrete and pipe }\end{array}$ & Short furrow & Modern & Vegetables, cercals & 25.00 & $\begin{array}{l}\text { Beyencech 2015; Mohammed and } \\
\text { TTefera 2017; Zeleke 2019; Adam } \\
\text { 2013; Yohannes 2011 }\end{array}$ \\
\hline 18 & Tibila & 1974 & 2,200 & Surface & Medium & Lined \& earthen & Furrow; basin & Modern & Vegetables, fruits & 26.00 & Adam 2013 \\
\hline 19 & Nura Era & 1974 & 3,070 & Surface & Medium & Unlined earthen & $\begin{array}{l}\text { Furrow } \\
\text { (siphon), basin }\end{array}$ & Modern & $\begin{array}{l}\text { Vegetables, cereals, } \\
\text { fruits, cotton tobacco }\end{array}$ & 25.00 & $\begin{array}{l}\text { Beshir and Awulachew 2007; } \\
\text { Halcrow } 1989\end{array}$ \\
\hline 20 & Jari & 2005 & 125 & Surface & Small & Lined masonry & $\begin{array}{l}\text { Flooding } \\
\text { furrow basin }\end{array}$ & Modern & $\begin{array}{l}\text { Vegetables, cereals, } \\
\text { fruits sugarcane }\end{array}$ & 29.00 & Solomon 2016 \\
\hline 21 & Aloma & 2012 & 115 & Surface & Small & $\begin{array}{l}\text { Masonry \& } \\
\text { earthen }\end{array}$ & Flooding & Modern & Vegetables, cercals & 26.00 & Solomon 2016 \\
\hline 22 & Adada & - & 16 & Surface & Small & $\begin{array}{c}\text { Masonry \& } \\
\text { earthen }\end{array}$ & Dyked basin & Traditional & Vegetables, cercals & 28.00 & Zerihun and Ketema 2006 \\
\hline 24 & $\begin{array}{l}\text { Kelena } \\
\text { Lemchek }\end{array}$ & $\begin{array}{l}1996 \\
2012\end{array}$ & $\begin{array}{l}643 \\
180\end{array}$ & $\begin{array}{l}\text { Surface } \\
\text { Surface }\end{array}$ & $\begin{array}{c}\text { Medium } \\
\text { Small }\end{array}$ & $\begin{array}{l}\text { Unlined } \\
\text { Lined \& earthen }\end{array}$ & Flooding & $\begin{array}{c}\text { Traditional } \\
\text { Modern }\end{array}$ & $\begin{array}{l}\text { Vegetables, cereals } \\
\text { Vegetables, cereals }\end{array}$ & $\begin{array}{l}40.00 \\
36.00\end{array}$ & $\begin{array}{l}\text { Zelcke et al } 2016 \\
\text { Alebachecu and Singh 2018; wB } \\
\text { and GIRDC } 2019\end{array}$ \\
\hline
\end{tabular}


In general, overall mean efficiency is below acceptable value recommended even for surface schemes i.e. $50 \%-60 \%$ efficiency is good; $40 \%$ is reasonable, and below $40 \%$ is poor (Brouwer et al. 1989).

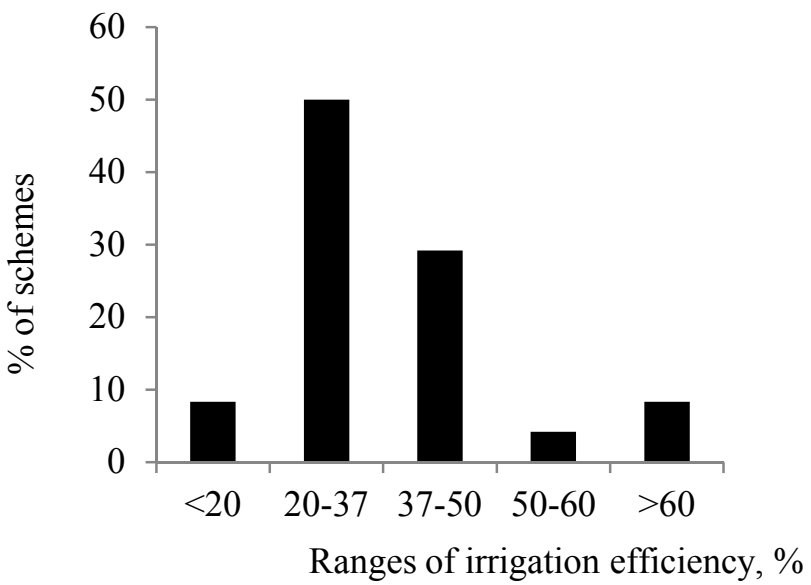

Fig 2 Microsoft Excel bar graph showing distributions of the studied 24 irrigation schemes relative to their overall mean efficiency $(37.06 \%)$.

Low efficiencies for most schemes such as Tibila, Nura Era and Gologota were associated with delivery of excess water (Beshir and Awulachew 2007; Adam 2013; Zeleke 2014). On the other hand, mismatch of canal capacity with irrigated area worsen efficiencies of schemes such as Tendaho and Ulaga zone 200. Tendaho is a 60,000 hectares scheme and construction of the main canal was completed without finalizing the farm lands resulted in diverting of excess water for only $19 \%$ of developed farm land which is also true for Fentale, Wellenchiti and Ulaga zone 200 schemes.

In spite of having similar operational modalities with others, exceptionally high efficiencies were reported for Bobe and Godino schemes which attributed to serious water shortages as reported by WB and GIRDC (2019), Zeleke (2014) and Zeleke et al. (2016).

\subsection{Surface versus Sprinkler Schemes}

Summary statistics for efficiencies of surface and sprinkler scheme categories are presented in Table 2. The hypothesis that for efficiencies of surface and sprinkler categories, the probability of surface efficiency being greater than sprinkler is equal to the probability of sprinkler being greater than surface or equality of the two samples have been tested using Mann-Whitney U test. Accordingly, the observed U value is compared with the critical U value.

Table 2 Summary statistics and Mann-Whitney nonparametric test results for efficiencies of surface and sprinkler irrigation scheme categories of Awash basin.

\begin{tabular}{lccccccccc}
\hline Categories & N & Mean & Median & Std. Dev. & Min & Max & $\begin{array}{c}\text { Sum } \\
\text { of } \\
\text { Ranks }\end{array}$ & U & Mann-Whitney critical U* \\
\hline Surface & 19 & 36.46 & 32.00 & 16.61 & 17.01 & 83.33 & 74 & 36.00 & $19^{* *}$ \\
Sprinklers & 5 & 39.33 & 45.00 & 17.30 & 14.03 & 59.00 & 226 & & \\
\hline
\end{tabular}

*https://www.real-statistics.com/statistics-tables/mann-whitney-table/; ** not statistically significant at $\rho<0.05$

Since the observed $U$ value was greater than the critical value, there is no significant difference between the two categories at 0.05 significance levels.

Relative to recommended standards, both categories had poor performances. Mean efficiency of surface category was almost 20\% lower than well managed flood irrigation 55\% (Perry and Steduto 2017) while the sprinkler was around $40 \%$ below the recommended $80 \%$.

The single Dodota center pivot had better efficiency which was $59 \%$, despite around $20 \%$ lower than its $80 \%$ design efficiency (Tsegaye 2019). Otherwise, mean efficiency of draglines was $34.41 \%$ (between $14.03 \%$ and $47.62 \%$ ) almost $45 \%$ lower than recommended. Ulaga zone-200 and Wake Tiyo dragline schemes had efficiencies even lower than mean of surface schemes.

Several problems associated with the dragline schemes were listed. The area where all the dragline and center pivot systems are operating is characterized by strong wind during the day time so that high evaporation and wind losses coupled with excess leakages at joints were stated as major causes (Dereje and Megersa 2015; Dereje et al. 
2017; Tadesse et al. 2018; Tsegaye 2019). Accordingly, application and distribution efficiencies of Wake Tiyo dragline were as low as $62 \%$ and 52.6\%, respectively. According to Calder (1976), coefficient of variation above $90 \%$ is excellent; between $80 \%$ and $90 \%$ is acceptable, between $70 \%$ and $80 \%$ is fair, and below $70 \%$ is considered as poor. Distribution efficiency as low as $60 \%$ can occur with systems on undulating topography, with worn nozzles, and/or under windy conditions but distribution uniformity less than $67 \%$ are generally considered as unacceptable (Merriam and Keller 1978). Very low efficiency of Ulaga zone-200 dragline, moreover, was also exacerbated by, according to Kassa (2015), pumping of excess water for partly developed area.

Effect of the wind was not serious for Dodota center pivot due to its water application method i.e. the nozzles sprayed the water directly at the top of the crop than throwing up like the draglines. Its mean application efficiency and uniformity were around $85 \%$ and $81 \%$, respectively with distribution uniformity of $72.62 \%$ (Tadesse et al. 2018; Tsegaye 2019). However, stoppage due to tire damage, pump failures, use of damaged and different nozzle sizes, and dirty water contributed for lowering efficiency of the system.

\subsection{FGP versus Ditch-Furrow Systems of Surface Schemes}

FGP schemes are the common type of surface methods except using pipes instead of earthen field ditches or channels to deliver irrigation water into the furrows. Although efficiency of FGP schemes of Awash basin seems much lower than the ditch systems, result of Mann-Whitney U test rejected efficiency differences to be significant (Table 3).

Table 3 Summary statistics and Mann-Whitney nonparametric test results for efficiencies of ditch-furrow and FGP surface irrigation scheme categories of Awash basin.

\begin{tabular}{lccccccccc}
\hline Categories & $\mathrm{N}$ & Mean & Median & Std. Dev. & Min & Max & $\begin{array}{c}\text { Sum of } \\
\text { Rank }\end{array}$ & U & Mann-Whitney critical U \\
\hline Ditches & 16 & 37.8 & 34 & 17 & 22 & 83.33 & 168 & 16 & $6^{*}$ \\
FGP & 3 & 29.34 & 25 & 15 & 17 & 46 & 22 & & \\
\hline
\end{tabular}

*Not statistically significant at $\rho<0.05$ for 16 and 3 number of samples

Median efficiency of the ditch system was by far higher than that of FGP schemes. Only Merti can be mentioned for its somehow acceptable efficiency which is the maximum of its category. Otherwise, mean of Tendaho and Wellenchiti was below 20\%. According to Solomon et al. (2017), the most dominant problems for all FGP schemes were tearing of pipes intensified by use of improper diameters and pressure heads, faulty installation, and so on. High volume of water was wasted through damaged pipes in excess of the anticipated savings from evaporation and seepage losses of the ditches systems. In additions, diverting excess water by Tendaho and Wellenchiti FGP schemes for partially developed irrigated areas aggravated the water losses thereby lowered the mean efficiency.

\subsection{Modern versus Traditional Schemes}

In Ethiopia, the classification of modern and traditional by default is used to categorize small scales only. However, in this paper the common definitions for modern and traditional schemes were used to for comparison regardless of their size so even medium scale sprinklers were grouped under modern scheme categories.

The numerical efficiency figures suggested that traditional schemes of the basin had somehow higher mean efficiency (Table 4). Despite having large differences between their maximum and minimum values, they had equal median value.

Table 4 Summary statistics and Mann-Whitney test results for efficiencies of modern and traditional scheme categories of Awash basin.

\begin{tabular}{lccccccccc}
\hline Categories & $\mathrm{N}$ & Mean & Median & Std. Dev. & Min & Max & $\begin{array}{c}\text { Sum of } \\
\text { Rank }\end{array}$ & U & Mann - Whitney critical U \\
\hline Modern & 20 & 36.40 & 34.00 & 15.70 & 14.03 & 83.33 & 249 & 39 & $14^{*}$ \\
Traditional & 4 & 40.36 & 34.00 & 22.02 & 22.00 & 71.43 & 51 & & \\
\hline
\end{tabular}

*Not statistically significant at $\rho<0.05$ for 20 and 4 number of samples

The Mann-Whitney U test revealed that efficiency difference between the two categories was insignificant at 0.05 significant levels which might be interpreted as; schemes constructed and managed by local farmers as well as schemes designed and constructed by skilled or qualified professionals diverted two times more water than crop demand. Performances of both categories were is poor which refutes the portraying of traditional schemes as an inefficient and poorly managed than modern schemes.

\subsection{Small, Medium and Large Scale Schemes}

All irrigation schemes were grouped into small (10 schemes), medium ( 9 schemes) and large ( 5 schemes) schemes 
based on size regardless of the technologies. Actually, the area weighted mean values of small, medium and large schemes which were $35.9 \%, 33.4 \%$ and $33.7 \%$, respectively indicated that all had comparable efficiencies. If efficiency values presented in Table 5 is examined, however, it appears that medium schemes were performing better than the two.

Table 5 Summary statistics and Kruskal-Wallis test results for efficiencies of small, medium and large scales irrigation schemes of Awash basin.

\begin{tabular}{lccccccccc}
\hline Scheme categories & $\mathrm{N}$ & Mean & Median & Std. Dev. & Min & Max & $\begin{array}{c}\text { Sum of } \\
\text { Ranks }\end{array}$ & $\mathrm{H}$ & Chi square, $\chi^{2}$ \\
\hline Small & 10 & 35.91 & 34.00 & 15.32 & 14.03 & 71.43 & 125.5 & $5.59^{*}$ \\
Medium & 9 & 39.59 & 31.00 & 20.35 & 22.00 & 83.33 & 112.5 & 0.002 & \\
Large & 5 & 34.80 & 43.00 & 12.97 & 17.01 & 46.00 & 62.0 & $\mathrm{df}=2$ \\
\hline
\end{tabular}

*Not significant at $\rho<0.05$ and the value was taken from Salvatore and Reagle (2002).

Median value of the large scale irrigation schemes was larger while the difference between the maximum and the minimum values was smaller.

In order to check whether the differences among the efficiencies were significant or not, Kruskal-Wallis test which is best suited method to compare more than two sample groups was performed based on the sum of ranks. The calculated $\mathrm{H}$ was smaller than the critical chi square value at 2 degree of freedom; hence, there is no significant difference among the groups at 0.05 significant levels $(\mathrm{H}(2)=0.0015, \mathrm{p}<0.05)$. Statistically, hence, all the three scheme categories including the 11,300 ha state owned Tendaho sugarcane scheme and 16 ha farmer managed small scale scheme had the same efficiency.

\section{DISCUSSION}

Irrigation schemes of Awash basin had poor efficiencies. It is difficult to single out one or two driving factors affecting the performances. Several engineering, institution and management related factors, separately or in combination, were reported in the reviewed papers listed in last column of Table 1. Among the listed intrinsic and common problems of all scheme categories of the basin complete absences of scheme operation and water management practices such as scheduling; were absence of water measuring and controlling structures; lack of maintenance services; lack of institutional and technical supports faulty design; poor quality and incomplete constructions and so on. For surface schemes, absence or improperly functioning water distributing, measuring and controlling structures; canal deformation and siltation; damages of pipes; water shortages; incomplete and/or poorly designed and/or constructed headwork and canals, and etc. were listed. Irrigating during strong wind; high leakages; low and fluctuating pressure heads were major causes for water losses from sprinkler schemes aggravated by pump failures; use of wrong nozzle size and poor water quality; shortages of spare parts and maintenance services; and power interruptions. Furthermore, according to Awulachew et al. (2005), poor technology choice, incorrect design, lack of knowledge about the use of modern technology, and poor water and land management are also some of the challenges which resulted in seepage, leakages, over irrigating, excess drains and so on problems in irrigation schemes.

Introducing of both FGP and sprinkler technologies demanded additional investments, operational rules, management setups, skills, commitments and etc. However, irrespective of their technologies and scheme categories, all schemes of the basin were managed in the same ways. In the first place, the maximum or attainable efficiencies of old surface methods were not exploited when the technologies were introduced. Institutional setups and activities as well as irrigation water and scheme management practices of the basin during the pre and post introduction eras were the same without any sign of improvement.

Water availability dictated irrigation intervals and how much to irrigate rather than moisture monitoring practices. High (satisfactory) or low efficiencies were not due to differences on scheme and water management practices rather attributed to water shortages and abundances, respectively due to either of the listed problems supporting the idea that there is universally a correlation between abundance and/or cost of water and irrigation efficiency. Where water is scarce or high in cost, efficiencies are higher whereas where water is abundant and/or low in cost; efficiencies are lower (Al-Jamal et al. 1997; Burt et al. 1997).

One aspect of modernization is the process of replacing irrigation infrastructure and methods with new or "modern" equipment and technologies with the aims of water saving, improved water delivery, and reduced operating and labor costs. On the contrary, sprinkler schemes of Awash basin performed like that of surface scheme while $20-30 \%$ water saving is expected, and also more than $70 \%$ of diverted water was wasted by FGP schemes let alone excelling the ditch methods. Hence, efficiency advantages could not be reflected on any of the introduced technologies as expected.

Comparable efficiencies of the traditional and modern schemes of the basin also ruled out the suggestion of 
several authors that smallholder (traditional) schemes in Ethiopia are characterized by poor on-farm water management practices and poor performances. While performing the same or below, a scheme might be classified even by policy makers as 'modern' due to its headwork conditions only without considering the management. Similarly, efficiencies of small, medium and large schemes categories of the basin were equally poor contradicting the common assumption that as farm size increases, operation and management will be complex to influence or reduce efficiencies. Hence, the issue of scale should consider particular circumstances and institutional capacities in the country concerned (FAO 1996).

Modernization implies change for the sake of improvement, not just change for the sake of change (Burt, 1996). FGP were introduced as alternative for ditch systems while sprinklers for surface at least to enhance efficiency but failed to bring the expected outcomes manifesting the importance of focusing on improving water management practices prior to adopting new technologies. According to FAO (2003), modernizing irrigation is contextual to local circumstances and modern technologies can only be introduced and used successfully where the users already possess the necessary skills. The technical side is only one aspect and equally important are changes in the institutions, regulations and efficacy of water users. It is a process of technical and managerial upgrading combined with institutional reforms, if required (Facon and Renault 1999).

\section{CONCLUSION}

In this study, 24 irrigation schemes of Awash River basin of Ethiopia were categorized and their irrigation efficiencies were compared. The comparisons were carried out between sprinklers versus surface schemes; surface schemes with ditch systems versus surface schemes with FGP; between traditional versus modern schemes; and, between small, medium and large scale schemes.

Accumulated digital and printed materials of numerous scholarly web sites and organizations were used as data sources and standard searching and filtering techniques were implemented. Efficiency related parameters being collected include RIS, conveyance, application and total efficiencies for surface methods including distribution uniformity for sprinklers. Since, the data were few in number and diverse in time and scale, they were normalized by using classical definition of irrigation efficiency. Due to the natures of the data, Mann-Whitney and Kruskal-Wallis nonparametric tests were used to statistically analyze and to compare two and three sample groups, respectively.

From the results, individual efficiencies of most of the studied irrigation schemes of the basin were found to be below recommended standards. Overall mean efficiency of the schemes was $37.06 \%$ (the value for area weighted mean was $33.67 \%$ ) ranged from $14.03 \%$ to $83.33 \%$. Out of the studied 24 schemes, only five achieved reasonable efficiencies i.e. above $50 \%$. Efficiency of the center pivot scheme was $59 \%$. Exceptionally high (above $70 \%$ ) and low efficiencies (below 20\%) were reported for two surface schemes due to critical water shortages and abundance respectively. Some dragline sprinkler schemes performed below some of surface schemes.

The nonparametric tests revealed that there is no significant efficiency difference among the scheme categories being tested. There is no efficiency advantage obtained from introducing of both FGP and sprinkler systems into the basin over surface schemes. Similarly, scheme sizes and infrastructure differences has no effect on efficiencies of Awash basin. Rather than management modalities, water availability dictated efficiencies of the schemes. High and low efficiencies were directly related with water shortages and abundances, respectively.

Results of the study strongly support the following conclusions which are directly related with the research questions being raised in the introduction part; 1) water shortages and abundances which are direct outcomes of poor irrigation water and scheme management and operations dictating irrigation efficiencies of the schemes; 2) efficiency enhancement was not gained due to the introduction of both FGP and sprinkler systems over surface methods so that adopting of modern technologies by itself cannot guarantee efficiency, and 3) performance variations were not manifested within irrigation scheme classifications of the basin. These conclusions have implications on future irrigation development plans of both Awash river basin and the country. Any irrigation development plan should prioritize and give paramount importance for improving of scheme and water management practices before adopting of any new technology into the irrigation sector.

Acknowledgments: the authors highly appreciate all who contributed for the data collection.

Conflicts of interests: the authors declare that they have no known conflict of interests that are relevant to the contents of this article.

\section{REFERENCES}

AAiT and AwBA (2018) Awash River Basin Water Allocation Modeling and Conflict Resolution Study Project. Final Report: WP3 Water Demand. Addis Ababa Institute of Technology (AAiT) and Awash Basin Authority (AwBA). Federal Democratic Republic of Ethiopia. Addis Ababa.

Beshir A and Awulachew S (2007) Analysis of Irrigation Systems Using Comparative Performance Indicators: A Case Study of Two Large-Scale Irrigation Systems in the Upper Awash Basin. International Water Management Institute, Addis Ababa. 
Adam TD (2013) Hydraulic and Hydrologic Factors on Conveyance Efficiency: Case of Fentale and Tibila Irrigation Schemes. Thesis, Addis Ababa University. Addis Ababa, Ethiopia.

Ahadi R, Samani Z and Skaggs R (2013) Evaluating on-farm irrigation efficiency across the watershed: A case study of New Mexico's Lower Rio Grande Basin. AWM 124 52-57. http://dx.doi.org/10.1016/j.agwat.2013.03.010.

Alebachew S and Singh P (2018) Evaluation of canal water conveyance and on farm water application for a small scale irrigation scheme in Ethiopia. International Journal of Water Resources and Environmental Engineering. Vol. 10(8), pp. 100-110. DOI:10.5897/IJWREE2018.0800.

Alemayehu S (2018) Performance Evaluation of Irrigation System (Wellenchiti Surface Irrigation Scheme). Thesis, Addis Ababa University Ethiopia.

Ali OAM and Mohammed ASH (2015) Performance Evaluation of Gated Pipes Technique for Improving Surface Irrigation Efficiency in Maize Hybrids. Agricultural Sciences, 6, 550-570. http://dx.doi.org/10.4236/as.2015.65055

AwBA (2017) Awash Basin Water Allocation Strategic Plan. Awash Basin Authority. Addis Ababa, Ethiopia.

AwBA (2018) Awash River Basin Atlas. Awash Basin Authority (AwBA). Addis Ababa, Ethiopia.

Awulachew S, Merrey D, Van Koopen B and Kamara A (2010) Roles, Constraints and Opportunities of SmallScale Irrigation and Water Harvesting in Ethiopian Agricultural Development: Assessment of Existing Situation. Workshop: 2010 March 14-16; Addis Ababa, Ethiopia: International Water Management Institute (IWMI).

Awulachew SB and Mekonen A (2011) Performance of Irrigation: An Assessment at Different Scales in Ethiopia. ExplAgric. volume 47 (S1), pp. 57-69.

Awulachew SB, Yilma AD, Loulseged M, Loiskandl W, Ayana M and Alamirew T (2007) Water Resources and Irrigation Development in Ethiopia. Working Paper 123. 78p. International Water Management Institute. Colombo, Sri Lanka.

Awulachew SB, Merrey DJ, Kamara AB, Van Koppen B, Penning de Vries F, Boelee E and Makombe G (2005) Experiences and opportunities for promoting small-scale/micro irrigation and rainwater harvesting for food security in Ethiopia. Colombo, Sri Lanka: IWMI. v.86p.

Bekele Y, Nata T and Bheemalingswara K. (2012) Preliminary Study on the Impact of Water Quality and Irrigation Practices on Soil Salinity and Crop Production, Gergera Watershed, Atsbi-Wonberta, Tigray, Northern Ethiopia, MEJS. 4(1): 29-46.

Belder P (2004) Effect of water-saving irrigation on rice yield and water use in typical lowland conditions in Asia, Agr. Water Manage., 65, 193-210.

Berhe FT, Melesse AM, Hailu D and Sileshi Y (2013) MODSIM-based Water Allocation Modeling of the Awash River Basin, Ethiopia. Catena, 109:118-128

Beyenech B (2015) Characterization and Performance Evaluation of Fentale Irrigation Development Project. Thesis. Addis Ababa University, Ethiopia.

Birhanu BH (2006) Performance assessment and benchmarking Irrigation schemes in Ethiopia: A case study of two irrigation schemes. Thesis, Institute for Water Education, Delft, the Netherlands.

Birhanu J, Kassahun A and Mekete T (1996) Wonji/Shoa cane plantation rehabilitation and development project study. Wonji research station. Wonji, Ethiopia.

Bittinger MW, Danielson RE, Evans NA, Hart WE, Morel-Seytoux HJ and Skinner MM (1979) Impact of Irrigation Efficiency Improvements on Water Availability in the South Platte River Basin. Technical Report No 13. Colorado Water Resources Research Institute, Colorado State University.

Bos MG (1980) Irrigation Efficiencies at Crop Production Level. ICID Bulletin 29, 2 18-26. New Delhi.

Bos MG (1985) Summary of ICID Definitions on Irrigation Efficiency. ICID Bulletin, 34(1): 28-31.

Bos MG (1997) Performance indicators for irrigation and drainage. Irrigation and Drainage Systems, 11:119-137. 112.

Bos MG and Nugteren J (1990) On irrigation efficiencies. ILRI publication 19. Wageningen, Netherlands.

Bos MG, Murray-Rust DH, Merrey DJ, Johnson HG and Snellen WS (1994) Methodologies for Assessing Performances of Irrigation and Drainage Management. Irrigation and Drainage Systems 7:231-261

Brouwer C, Prins K and Heibloem M (1989) Irrigation Scheduling, Irrigation Water Management Training manual no. 4. FAO. Rome.

Burt CM, Clemmens AJ, Strelkoff TS, Solomon KH and Bliesner RD (1997) Irrigation performance measures: efficiency and uniformity. Journal of Irrigation and Drainage Engineering 123: 423-442.

Burt C.M (1996) Modern Water Control and Management Practices in Irrigation: Methodology and Criteria for Evaluating the Impact on Performance. Proceedings on Modernization of Irrigation Schemes: Past Experiences and Future Options. Thailand. 26-29 Nov. FAO. http://www.itrc.org/papers/modwatercontrol/m pdf ITRC Paper 96-001.

Burt CM and Styles S (2007) Drip and Microirrigation for trees, vines and row crops The Irrigation Training and 
Research Center, California Polytechnic State University, California. http://www.itrc.org/publications.htm

Cai X, Ringler C and Rosegrant MW (2006) Modeling Water Resources Management at the Basin Level: Methodology and Application to the Maipo River Basin. Washington, DC, USA. IFPRI Research Report 149. $151 \mathrm{p}$.

Calder TC (1976) Efficiency of sprinkler irrigation systems. Journal of the Department of Agriculture, Western

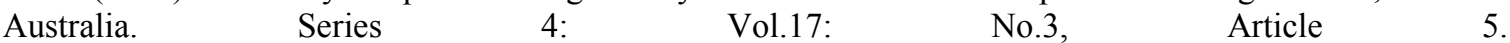
https://researchlibrary.agric.wa.gov.au/journal_agriculture4/vol17/iss3/5

Clemmens AJ, and Dedrick AR (1994) Irrigation techniques and evaluations. Advanced series in agricultural sciences, Springer-Verlag, Berlin, Germany, pp. 64-103.

Darouich H, Cameira MR, José M, Gonçalves J.M, Paredes P and Pereira LS (2017) Comparing Sprinkler and Surface Irrigation for Wheat Using Multi-Criteria Analysis: Water Saving vs. Economic Returns. Water 2017, 9, 50; DOI:10.3390/w9010050.

Darouich H, Gonçalves J.M, Muga A and Pereira LS (2012) Water saving vs. farm economics in cotton surface irrigation: An application of multicriteria analysis. Agric. Water Manag. 115, 223-231.

Dereje B and Megersa O (2015) Evaluating the Effect of Operating Pressure and Riser Height on Irrigation Water Application under Different Wind Conditions in Ethiopia. Asia Pacific Journal of Energy and Environment, Volume 2. Number 1/2015.No 1/2015 ISSN 2313-0008 (Print); ISSN 2313-0016 (Online).

Dereje B, Megersa O, and Tilahun H (2017) Effects of Operating Pressure, Nozzle Diameter and Wind Speed on the Performance of Sprinkler in Irrigation System during Water Application. Journal of Advanced Research, Volume 6, No 2 (2017). ISSN 2304-2621(p); 2312-203X (e).

Dinar A and Yaron D (1992) Adoption and abandonment of irrigation technology, Agr. Econ., 6, 315-332.

Edossa Ch (2014) Irrigation and Nutrient Management Studies on Vegetable Crops with Particular Reference to Tomato (Lycopersicum Esculentum M.) in the Central Rift Valley of Ethiopia. Dissertation, Haramaya University.

Endalkachew G (2012) Climate Change Impact on Surface Water Sources of Addis Ababa case study LegedadiDire-Gefersa Catchments and Reservoirs. Addis Ababa institute of Technology, Addis Ababa.

EPCC (2015) First Assessment Report-Working Group II Water and Energy, Published by the Ethiopian Academy of Sciences. Ethiopian Panel on Climate Change (EPCC), Addis Abeba.

Erkin H (1997) The use of water pumps and energy savings in Trakya Region. $2^{\text {nd }}$ Industrialization and Environment Symposium. Edirne, Turkey. pp. 351-362.

Facon T and Renault D (1999) Modernization of irrigation system operations. Proceedings of the 5th ITIS network international meeting, Aurangabad, 28-30 October 1998. http://www.watercontrol.org/.

FAO (1965) Report on Survey of the Awash River Basin; Volume I General Report. FAO/SF: 10/ETH. Food and Agriculture Organization of the United Nations. Rome.

FAO (1996) Guideline for Planning Irrigation and Drainage Investment Projects. FAO Investment Centre Technical Paper Series No. 11. Rome, Italy.

FAO (2003) Unlocking the Water Potential of Agriculture. Food and Agriculture Organization of the United Nations, Rome, Italy.

Gebremeskel T and Mekonen A (2015) Evaluation of the Effects of Current Irrigation Water Pricing Systems on Water Productivity in Awash River Basin, Ethiopia. African Journal of Agricultural Research. Vol. 10(14), pp. 1789-1795, DOI: 10.5897/AJAR2013.7541. ISSN 1991-637X.

Gedion TS (2009) Surface Water-Groundwater Interactions and Effects of Irrigation on Water and Soil Resources in the Awash Valley. Thesis. Addis Ababa University, Ethiopia.

Giordano M, Turral H, Scheierling SM, Tréguer DO and McCornick PG (2017) Beyond "More Crop per Drop": evolving thinking on agricultural water productivity. International Water Management Institute (IWMI); Research Report 169. Colombo. Doi: 10.5337/2017.202.

Girma A and Solomon M (2014) Assessment of Soil Salinity and Ground Water Condition in some Sugarcane Fields at Tendaho Sugar Project (Specifically at PC-I): Advisory, Research and Training No 3: 1-13. Wonji.

Hachum A (2006) Performance Evaluation of Sprinkler Irrigation Systems: Symposium on Irrigation Modernization, International Programme for Technology and Research in Irrigation and Drainage, Syria. http://dotproject.fao.org/syria/hachum.pdf,1-24.

Hagos F, Makombe G, Namara RE and Awulachew SB (2009) Importance of irrigated agriculture to the Ethiopian economy: Capturing the direct net benefits of irrigation. International Water Management Institute (IWMI Research Report 128) 37p. Colombo.

Haile GG and Kassa AK (2015) Irrigation in Ethiopia: A review. Acad. J. Agric. Res. 3(10): 264-269. DOI: 10.15413/ajar.2015.0141.ISSN: 2315-7739.

Haileslassie A, Agide Z, Erkossa T, Hoekstra D, Schmitter P and Langa S (2016) On-Farm Smallholder Irrigation Performance in Ethiopia: From Water Use Efficiency to Equity and Sustainability LIVES Working Paper 19. International Livestock Research Institute (ILRI), Nairobi, Kenya. 
Halcrow (1983) Water Management Manual. Amibara Irrigation Project. Water Resources Development Authority, Ethiopia.

Halcrow (1989) Master Plan for the Development of Surface Water Resources in the Awash Basin. Final Reports: Volume 4. Ethiopian Valley Development Studies Authority.

Hanson B, Bowers W, Davidoff B, Kasapligil D, Carvajal A and Bendixen W (1996) Field Performances of Micro irrigation Systems. In: Proceedings of the Fifth International Micro irrigation Congress, Orlando, FL, pp. 769-774.

Hassan SA (1998) Engineering studies for increasing water distribution uniformity of perforated pipes for surface irrigation system. Dissertation, Agric. Eng. Dept., Cairo Univ.

Howell TA (2003) Irrigation Efficiency. Encyclopedia of Water Science. USDA, Bush land, Texas, U.S.A. DOI: 10.1081/E-EWS 120010252

Jägermeyr J, Gerten D, Heinke J, Schaphoff S, Kummu M and Lucht W (2015) Water saving potentials of irrigation systems: global simulation of processes and linkages. Hydrol. Earth Syst. Sci., 19, 3073-3091. www.hydrol-earth-syst-sci.net/19/3073/2015/. DOI:10.5194/hess-19-3073-2015.

Jensen ME (2007) Beyond irrigation efficiency. Irrigation Sci. 25 (3), 233-245. http://dx.doi.org/10.1007/s00271007-0060-5.

Jensen ME (1967) Evaluating Irrigation Efficiency. J. Irrig. and Drain. Div., Am. Soc. Civil Engr. 93(IR1):83-98.

Jensen ME (1993) Impacts of Irrigation and Drainage on the Environment. Fifth Gulhati Memorial Lecture. Proc. $15^{\text {th }}$ ICID Congress. The Hague, Netherlands.

Jensen ME, Swarner LR and Phelan JT (1967) Improving irrigation Efficiencies. In: Irrigation of Agricultural Lands. Agronomy Series: 11, p 1120-1142, Wisconsin, USA.

Karimi P, Bastiaanssen WGM, Sood A, Hoogeveen J, Peiser L, Bastidas-Obando E and Dost R (2014) Spatial evapotranspiration, rainfall and land use data in water accounting -Part 2: Reliability of water accounting results for policy decisions in Awash basin. Hydrol. Earth Syst. Sci. Discuss., 11, 1-44, 2014. DOI:10.5194/hessd-11-1-2014.

Kassa T (2015) Performance Evaluation of Wonji-Shoa Irrigation Schemes (Case Study of Ulaga Irrigation Project). Thesis. Arba-Minch University, Ethiopia.

Keller AA and Keller J (1995) Effective Efficiency: A Water Use Efficiency Concept for Allocating Freshwater Resources. Discussion Paper 22. Center for Economic Policy Studies, Winrock International.

Keller J and Bliesner RD (2000) Sprinkle and Trickle Irrigation. The Blackburn Press: Caldwell, NJ, $2000 ; 652$.

Levidowa L, Zaccariab D, Maiac R, Vivasc E, Todorovicd M and Scardigno A (2014) Improving water-efficient irrigation: Prospects and difficulties of innovative practices. AWM 146 (2014) 84-94. http://dx.doi.org/10.1016/j.agwat.2014.07.012.

Mahtsente TT, Lalit K, Koech R and Birhanu Z (2019). Hydro-Climatic Variability: A Characterization and Trend Study of the Awash River Basin, Ethiopia. Hydrology 2019, 6, 35; doi:10.3390/hydrology6020035.

Makombe G, Namara RE, Awulachew SB, Hagos F, Ayana M and Kanjere M (2017) An analysis of the productivity and technical efficiency of smallholder irrigation in Ethiopia. Water SA Vol. 43 No. 1. http://dx.doi.org/10.4314/wsa.v43i1.08

Makombe G, Namara R, Hagos F, Awulachew SB, Ayana M and Bossio D (2011) A Comparative Analysis of Technical Efficiency of Rain-Fed and Small Holder Irrigation in Ethiopia. International Water Management Institute. pp. 37. Colombo.

Mateos L (1998) Assessing whole-field uniformity of stationary sprinkler irrigation systems. Irrig Sci (1998) 18:73-81, Spain.

Mengistu B, Abera D, Dereje B and Solomon M (2017) Evaluation of the Hydraulic Performance of Flexible Gated Pipe Irrigation System at Metehara sugar Estate. Research Report. Research and Training, Wonji.

Merkley GP and Allen RG (2004) Sprinkle \& Trickle Irrigation. Biological and Irrigation Engineering Department. Utah State University, Utah

Merriam JL and Keller J (1978) Farm Irrigation System Evaluation: A Guide for Management; Utah State Univ. Logan, UT; 271.

Mishra A, Anand A, Singh R and Raghuwanshi NS (2001) Hydraulic Modeling of Kangsabati Main Canal for Performance Assessment. J. Irrigation Drainage Eng., 127(1): 27-34.

Mohammed M and Tefera A (2017) Effect of Reference Conveyance Parameter Usage on Real Time Canal Performance: The Case of Fentale Irrigation Scheme in Ethiopia. Computational Water, Energy, and Environmental Engineering, 6, 79-88. http://dx.doi.org/10.4236/cweee.2017.61006 .

Molden D, Sakthivadivel R, Perry CJ, de Fraiture C and Kloezen WH (1998) Indicators for comparing performance of irrigated agricultural systems. IWMI Research Report 20.

MoWIE (2020) Ten years (2020/21-2029/30) Development Plan. Federal Democratic Republic of Ethiopia, Ministry of Water, Irrigation and Energy (MoWIE). Addis Abeba, Ethiopia (Amharic Version).

MoWR (2001) Ethiopian Water Sector Policy. Federal Democratic Republic of Ethiopia, Ministry of Water 
Resources (MoWR). Addis Ababa, Ethiopia.

Mukherji JP (2001) Rehabilitation, Optimization and Expansion of Agriculture and Factory. Final report, Volume I and III. Addis Ababa, Ethiopia.

Nachar N (2008) The Mann-Whitney U: A Test for Assessing Whether Two Independent Samples Come from the Same Distribution. Tutorials in Quantitative Methods for Psychology. 2008, vol. 4(1), p. 13-20.

Omara AI (1997) Implementation and evaluation of gated pipe for furrow irrigation system. Thesis, Agric. Eng. Dept., Alex. Univ., Egypt

Ostertagová E, Ostertag O and Kováč J (2014) Methodology and Application of the Kruskal-Wallis Test. Applied Mechanics and Materials Vol. 611 (2014) pp115-120. DOI:10.4028/www.scientific.net/AMM.611.115. (accessed in December 15 2020).

Paulos D, Menkir M, Moltot Z and Lijalem Z (2002) Agriculture, irrigation and drainage research in the past and the future; In, Integrated Water and Land Management Research and Capacity Building Priorities for Ethiopia, Proceedings of MoWR/EARO/IWMI/ILRI International Workshop, Addis Ababa, Ethiopia.

Pereira LS and Oweis T Zairi (2002) Irrigation management Under Water Scarcity. Agric. Water Manag. 2002, 57 , 175-206.

Perry C and Steduto P (2017) Does Improved Irrigation Technology Save Water? A Review of the Evidence. Discussion paper on irrigation and sustainable water resources management in the Near East and North Africa. Food and Agriculture Organization. CAIRO.

Perry C, Steduto P, Allen RG and Burt CM (2009) Increasing productivity in irrigated agriculture: agronomic constraints and hydrological realities. Agric.Water Manage. 96, 1517-1524.

Rahmato D (1999) Water Resource Development in Ethiopia: Issues of Sustainability and Participation. FSS Discussion Paper. www.ethiopians.com/Main_FSS_Paper1.htm (accessed in September 24, 2020)

Renault D and Godaliyadda GA (1999) Generic typology for irrigation systems operation. International Water Management Institute (IWMI). Research Report 29. Colombo, Sri Lanka: ISBN 92-9090-372-4; ISSN 10260862 .

Rudnick DR and Irmak S (2015) Introduction $E^{3} A$ : Irrigation Efficiency. University of Nebraska-Lincoln, University of Wyoming Extension. B-1264|E3A-IE.I www.wyoextension.org/publications/ Accessed September 10, 2020.

Salvatore D and Reagle D (2002) Theory and Problems of Statistics and Econometrics. Schaum's Outline Series, second edition. The McGraw-Hill, United States of America. DOI: 10.1036/0071395687.

Shifflett SC, Turner JL, Dong L, Mazzocco I and Yunwen B (2015) China's Water-Energy-Food Roadmap; A Global Choke Point Report. Woodrow Wilson International Center for Scholars. New York.

Shimelis A (2004) Optimal Scheduling of Water Distribution of Melka-Sedi Diversion Weir. Thesis. Haramay University, Ethiopia.

Smith RJ and Gillies MH (2009) Head Ditch Hydraulics and the variability of Inflows to Irrigation furrows. John Wiley \& Sons Ltd, 59 (4): 442-452. DOI: 10.1002/ird.495

Solomon A, Yusuf K. and Alamirew T (2017) Effects of slopes, furrow lengths and inflow rates on irrigation performances and yield of sugarcane plantation at Metehara, Ethiopia. Irrigation \& Drainage Systems Engineering. Volume 6: Issue 1-1000179.

Solomon WT (2016) Performance Evaluation of Irrigation Schemes: A Case Study of Jari and Aloma Small-Scale Irrigation Schemes, Tehuledere District, Ethiopia. Thesis. Arba Minch University, Ethiopia.

Stuart CA and Dave T (2009) Understanding Water Risks: A Primer on the Consequences of Water Scarcity for Government and Business; WWF Water Security Series; Washington, DC, USA.

Tadesse G (2017) Performance Evaluation of Field Water Application at Tendaho Sugar Estate, Ethiopia. Irrigat Drainage Sys Eng 6: 199.

Tadesse G, Mengistu B, Fikadu K., Solomon M and Dereje B (2018) Evaluation of irrigation water application practices in sprinkler irrigation of expansion areas of Wonji/Shoa sugar estates. Research Result, Wonji.

Tefera W (1986) Development of Drainage in the Middle Awash Valley of Ethiopia. Water Resources Development Authority, Addis Ababa, Ethiopia.

Tilly L and Chapman L (1999) Benchmarking Crop Water Index for the Queensland Sugar Industry, Bureau of Sugar Experiment Stations, Brisbane.

Tsegaye ML (2019) Comparison of Dragline and Center Pivot Sprinkler Irrigation Methods Using Performance Indicators: The Case of Wonji-Shoa Sugar Factory, Ethiopia. Thesis, Addis Ababa Science and Technology University, Ethiopia.

WB and GIRDC (2019) Evaluation of Infrastructures and Performance Assessment of Small-Scale Irrigation Schemes Constructed During the First Phase of Agricultural Growth Program (AGP-I); Performance Assessment Draft Final Main Report. World Bank Group and Generation Integrated Rural Development Consultant (GIRDC). Addis Ababa, Ethiopia.

World Bank (2006) Ethiopia: Managing Water Resources to Maximize Sustainable Growth; Agriculture and Rural 
Development Department: Washington, DC, USA.

WWDSE (2013) Tendaho Sugarcane Irrigation Expansion Project: Final Basin Water Balance Assessment Report. Water Works Design and Supervision Enterprise. Addis Ababa, Ethiopia.

Yibeltal T (2013) Synthesis Report: Awash River Basin Water Audit, Addis Ababa, Ethiopia. Food and Agriculture Organization (FAO) and Federal Democratic Republic of Ethiopia. Addis Abeba.

Yohannes GS (2011) Large Scale Irrigation Management and Critical Environmental Concern: The Case of Fentale Irrigation Project in Central Oromiya. Thesis, Addis Ababa University.

Yusuf Kedir (2021) The Stumbling Irrigation Sector of Ethiopia: Critical Review and Analysis. Irrigat Drainage Sys Eng, Volume 10:2. 2021.

Yusuf, K. (2015) Estimation of Conveyance losses of Wonji Shoa irrigation scheme, Ethiopia. Journal of Environment and Earth Science. Vol.5, No.17.

Yusuf K, Alamirew T and Pauslos D (2007) Performance Assessment of Small-Scale Irrigation Schemes Using Comparative Indicators: a case in Awash River Basin of Ethiopia. Ethiopian Journal of Natural Resources (EJNR), Vol 9, Number 2.

Zeleke A (2014) Hydraulic and Operational Performance of Irrigation Schemes in View of Water Saving and Sustainability. Dissertation, UNESCO-IHE. ISBN 978-1-138-02767-1CRC Press/Balkema.

Zeleke A (2019) Determinants of Efficient and Sustainable Water Management in Community based Large Scale Irrigation Schemes: Case of Fentale Irrigation Scheme, Awash Basin. Research Report. Addis Ababa.

Zeleke A, Haileslassie A, Sally H, Erkossa T, Schmitter P, Langan S and Hoekstra D (2016) Analysis of water delivery performance of smallholder irrigation schemes in Ethiopia: Diversity and lessons across schemes, typologies and reaches. LIVES Working Paper 15. Kenya: International Livestock Research Institute (ILRI).

Zemede A (2011) Ethiopia and the River Awash Basin; Situational Analysis 3. Water Futures: Assessing pathways, synergies and tradeoffs in alleviating poverty through sustainable ecosystem services in Sub-Saharan Africa. RiPPLE and Water Futures Consortium. Addis Ababa, Ethiopia.

Zerihun B and Ketema T (2006). On-farm performance evaluation of improved traditional small-scale irrigation practices: A case study from Dire Dawa area, Ethiopia. Irrigation and Drainage Systems 20: 83-98.

Zhao X, Jin J, and Wu P (2010) Impact of climate change and irrigation technology advancement on agricultural water use in China, Climatic Change, 100, 797-805. 